AUTHOR CORRECTION OPEN

\title{
Author Correction: Please give me a copy of my child's raw genomic data
}

Lauren Chad and Michael J. Szego

npj Genomic Medicine (2021)6:26; https://doi.org/10.1038/s41525-021-00191-y

Correction to: npj Genomic Medicine https://doi.org/10.1038/ s41525-021-00175-y, published online 17 February 2021

The original version of this Article contained an error in the author affiliations.

Affiliation number 2 incorrectly read 'Department of Bioethics, The Hospital for Sich Children, Toronto, ON, Canada'

This has now been corrected in both the PDF and HTML versions of the Article. (c) (i) Open Access This article is licensed under a Creative Commons Attribution 4.0 International License, which permits use, sharing, adaptation, distribution and reproduction in any medium or format, as long as you give appropriate credit to the original author(s) and the source, provide a link to the Creative Commons license, and indicate if changes were made. The images or other third party material in this article are included in the article's Creative Commons license, unless indicated otherwise in a credit line to the material. If material is not included in the article's Creative Commons license and your intended use is not permitted by statutory regulation or exceeds the permitted use, you will need to obtain permission directly from the copyright holder. To view a copy of this license, visit http://creativecommons. org/licenses/by/4.0/.

(c) The Author(s) 2021 